Volume. 3 Nomor. 1

Periode: Januari - Juni 2019; hal. 16-27

p-ISSN : 2580-1112; e-ISSN : 2655-6669

Copyrighr @2019

Penulis memiliki hak cipta atas artikel ini

Jurnal Ilmiah Keperawatan Orthopedi

(JIKO)

journal homepage: https://ejournal.akperfatmawati.ac.id

\title{
Studi Fenomenologi : Pengalaman Perubahan Fungsi Seksual Pada Klien Dengan Cedera Medula Spinalis
}

\author{
Harun Al Rasid ${ }^{1}$, Masfuri ${ }^{2}$, I Made Kariasa ${ }^{3}$ \\ Departemen Keperawatan Medikal Bedah, Fakultas Ilmu Keperawatan, Universitas \\ Indonesia, Depok
}

\begin{abstract}
Abstrak
Cedera Medula Spinalis (CMS) mengakibatkan deficit neurologis yang mempengaruhi seksualitas. Seksualitas merupakan bagian integral dari kehidupan yang kompleks dan oleh sebagian besar klien dianggap tabu (taboo) untukdi diskusikan terutama di Indonesia. Seksualitas merupakan bagian integral dari kehidupan seseorang dan oleh sebagian besar klien dianggap tabu (taboo) untuk didiskusikan terutama di Indonesia. Penelitian ini bertujuan untuk mendapatkan gambaran makna dari pengalaman perubahan fungsi seksual pada klien dengan cedera medulla spinalis. Desain penelitian adalah penelitian kualitatif dengan pendekatan fenomenologi pada enam partisipan. Pengumpulan data dengan wawancara mendalam dan catatan lapangan. Analisa data menggunakan metode Collaizi. Penelitian ini menghasilkan enam buah tema yaitu 1) kesedihan akibat kelemahan/perubahan fisik, 2) perubahan fungsi seksual, 3) respon psikologis terhadap perubahan fungsi seksual, 4) cara mengekspresikan fungsi seksual, 5) harapan untuk memenuhi kebutuhan seksual dan 6) harapan terhadap pelayanan keperawatan di rumah sakit dalam mengatasi masalah kebutuhan seksual. Hasil penelitian diatas dapat dijadikan dasar penelitian lebih lanjut.
\end{abstract}

Kata Kunci : Cedera Medula Spinalis, Seksualitas, Perubahan Fungsi Seksual

\begin{abstract}
Spinal cord injury (SCI) impacxt on neurological deficits and sexuality. Sexuality is an integral part of the individual life which is complex problems at the issues are that considered taboo (taboo) to be discussed, especially in Indonesia. The purpose of this study was to get an idea of the significance of experience changes in sexual function in clients with spinal cord injury. This is a qualitative study with phenomenological approach involving six participants. Collecting data with in-depth interviews and field notes. Data were analyzed with Collaizi's method. The result found six themes,1) sadness due to weakness / physical changes, 2) change in sexual function, 3) the psychological response to changes in sexual function, 4) how to express sexual function, 5) hopes for the sexual needs and 6) expectations of nursing care in hospitals addressing sexual needs. That study can be used further studies.
\end{abstract}

Keyword : Spinal Cord Injury, Sexuality, Changes of Sexual Function

1,2,3 e-mail: ns.alrasidkmb13@gmail.com 


\section{Pendahuluan}

Cedera medula spinalis (CMS) atau spinal cord injury (SCI) masih merupakan masalah kesehatan mayor yang harus diperhatikan karena mempengaruhi 150.000 sampai 500.000 orang hampir di setiap negara, dengan perkiraan 10.000 cedera baru yang terjadi setiap tahunnya. Setengah dari kasus ini akibat kecelakaan lalu lintas, selain itu akibat jatuh, olah raga, kecelakaan kerja dan akibat luka tembak, serta merupakan salah satu penyebab utama disabilitas neurologis yang diakibatkan trauma yang menyebabkan hilangnya fungsi genitourinary, gastrointestinal, motorik, sensorik, dan fungsi seksualitas (Benevento, Barbara T dan Sipski, 2002)

Cedera Medula spinalis ( CMS) menimbulkan kerusakan fungsi neurologis yang disebabkan oleh benturan pada daerah medula spinalis (Smeltzer, Hinkle, Bare, \& Cheever, 2010)

Menurut Ignatavius dan Workman (2006), CMS adalah fraktur atau lepasnya satu atau lebih dari bagian vertebra yang menyebabkan kerusakan pada medula spinalis dan akar syaraf sehingga terjadi defisit neurologis dan sensori persepsi atau kelemahan keduanya yang pada akhirnya akan mengakibatkan kehilangan sebagian atau keseluruhan fungsi rasa dan gerak dibawah daerah cedera. Sedangkan menurut (WHO, 2013), CMS adalah semua lesi pada spinal cord, conus medullaris dan cauda equina yang menyebabkan kerusakan pada medula spinalis akibat trauma dan non trauma.

Data Statistik Nasional Cedera Medula Spinalis (Centre, 2014) menyebutkan bahwa ada sekitar 40 kasus per satu juta populasi atau sekitar 12.000 kasus baru cedera medula spinalis terjadi di Amerika Serikat namun tidak termasuk yang meninggal saat kejadian per tahun.
Berdasarkan data dari Korlantas Mabes Polri (Polri, 2013) disebutkan bahwa sepanjang tahun 2012 jumlah korban meninggal akibat kecelakaan lalu lintas di Indonesia mencapai 118 ribu kasus kecelakaan dimana korban meninggal dunia mencapai 29.544 jiwa.

Jumlah kecelakaan pada tahun 2012 tersebut meningkat $8 \%$ dari angka kecelakaan pada tahun 2011 yang mencapai 109.776 kasus kecelakaan. Angka kecelakaan pada tahun 2012 tersebut menyebabkan kerugian materil mencapai 298 milyar rupiah dimana kerugian materil tersebut juga ikut meningkat sekitar 5\% dari kerugian materil pada tahun 2011 yang mencapai 286 milyar rupiah.

Medula spinalis berfungsi sebagai jembatan sistem komunikasi diantara otak sebagai penerima informasi sebelum memberikan satu perintah, dan sistem syaraf perifer yang bertugas mengontrol fungsi pernafasan, irama jantung, tekanan darah, keringat, pengontrol suhu, berkemih, buang air besar, seksual, dan fungsi organ vital lainnya (Dumont et al., 2001; Shepherd Center, KPKinteractive, Society, Association, \& Foundation, 2011). Cedera primer menyebabkan kerusakan permanen secara klinis (Dumont et al., 2001).

Dampak penting lainnya akibat CMS yang sering terjadi yaitu pada genitourinary, gastrointestinal, dan fungsi seksual. Fungsi area ini sangat penting bila terganggu akibat CMS, namun dampaknya tergantung dari derajat dan tingkat kerusakan syaraf (Benevento, Barbara T dan Sipski, 2002). Pada laki-laki terjadi perubahan secara fisik mengenai pengontrolan aktivitas seksual, seperti erection, ejaculation, dan persepsi orgasm, serta perubahan perilaku seksualnya.

Fungsi ereksi dapat terjadi dalam 2 cara, yaitu: pertama reflek terjadi melalui sacral stimulation dan jalur 
parasymphathetic neurologic, kedua psychogenically dibawah kontrol hypogastric plexus pada T11 - L2 dan juga segmen sacral. Pada perempuan, kemampuan untuk mengalami psychogenic genital vasocongestion (berhubungan dengan kelembaban organ kewanitaan).

Kebutuhan seksualitas tetap menjadi komponen yang penting dari aspek sosial, psikologi, dan biologi bagi setiap manusia. Permasalahan mengenai seksualitas pada klien dengan CMS masih perlu dieksplorasi lebih lanjut terutama di Indonesia karena sampai saat ini permasalahan seksual masih dianggap hal yang tabu untuk diperbincangkan dan belum dipublikasikan.

Perubahan fungsi seksual yang terjadi setelah cedera medula spinalis dapat menimbulkan rasa bersalah dan penolakan tidak hanya dari diri sendiri akan tetapi bisa datang dari pasangan baik yang belum menikah maupun yang sudah menikah dan hidup berumah tangga serta mempunyai keturunan sehingga menyebabkan permasalahan dalam pola hubungan pasangan yang serius.

\section{Metode}

Penelitian ini merupakan penelitian kualitatif dengan pendekatan fenomenologi. Partisipan adalah seluruh pasien CMS yangt sudah menikah dan sudah pernah dirawat di RSUP Fatmawati. Partisipan dipilih dengan menggunakan tehnik purposive sampling (sesuai tujuan) dengan fokus penelitian kualitatif dengan kedalaman dan proses serta pencapaian saturasi dan variasi data. Penelitian ini melibatkan 6 orang partisipan.

Penelitian dilakukan di RSUP Fatmawati dengan memperhatikan prinsip-prinsip etik, yaitu respect for human dignity, 2) respect for free and informed consent, 3) respect for vulnerable persons, 4) respect for privacy and confidentiality, 5) respect of justice and inclusiveness, 6) balancing harms and benefits, 7) minimizing harm, 8) maximazing benefit (Loiselle, Profetto, Polit \& Beck, 2011).

Pengumpulan data dilakukan dengan metode wawancara mendalam ditambah dengan catatan lapangan. Adapun tahapan pengumpulan data terdiri dari tiga tahap diawali dengan pembuatan surat keterangan lolos kaji etik dari Komite Etik Penelitian FIK UI dilanjutkan dengan mendapatkan izin dari rumah sakit tempat penelitian dilaksanakan. Tahap kedua peneliti melakukan orientasi terhadap partisipan dengan membina hubungan saling percaya, melakukan pendekatan yang disesuaikan dengan latar belakang sosial budaya agar partisipan merasa nyaman dan dapat memberikan informasi yang dibutuhkan. Tahap ketiga yaitu pengumpulan data menggunakan wawancara mendalam. Sebelum dilakukan wawancara, calon partisipan diberikan penjelasan tentang maksud dan tujuan penelitian dengan memberikan informed consent.Wawancara dilakukan selama 45-60 menit dilengkapi dengan digital voice recorder dan catatan lapangan. Pada tahap terminasi dilakukan konfirmasi hasil wawancara pada semua partisipan.

Manajemen data dilakukan pada hasil wawancara dan catatan lapangan. Hasil dokumentasi dibuat dalam bentuk transkrip verbatim yang disimpan dalam file word dan dijadikan folder selanjutnya disimpan dalam hard disk laptop dan diberikan password. Analisis data dilakukan menggunakan model Collaizi (1978) yaitu dengan melakukan klarifikasi hasil analisa data dengan mendatangi kembali saat diperlukan konfirmasi data.

Adapun keabsahan data dalam penelitian ini menggunakan prinsip credibility (kredibilitas), dependability (kestabilan data), confirmability (objektivitas), dan transferability 
(validitas) (Afiyanti \& Rachmawati, 2014).

\section{Hasil Penelitian}

Penelitian ini melibatkan 6 (enam) orang partisipan yang terdiri dari 2(dua) orang perempuan dan 4(empat) orang laki-laki. Usia rata-rata 35.7 tahun dengan rentang usia termuda 32 tahun dan tertua 44 tahun. Semua partisipan beragama islam dengan pendidikan 2 orang tamat SMP, 3 orang tamat SMA, 1 orang tamat D3, status pekerjaan bervariasi yang antara lain 1 orang sebagai ibu rumah tangga, dan 1 orang lagi sebagai penjahit di panti, 2 orang karyawan swasta, dan 1 orang anggota POLRI.

Lokasi CMS pada dua orang perempuan pada thorakal 11-12 yang mengakibatkan kedua kaki lumpuh tidak mampu digerakan, kehilangan rasa mulai dari perut sampai ujung kaki. Dua orang laki-laki terkena luka tusuk dan luka tembak di thorakal 4-6 sehingga kedua kaki lumpuh tidak mampu digerakan dan kehilangan rasa mulai dari dada sampai ujung kaki, 1 orang laki-laki mengalami fraktur dislokasi pada thorakal 4-8, kehilangan rasa mulai dari dada sampai ujung kaki, dan 1 orang laki-laki mengalami infeksi tulang pada thorakal 5-7 sehingga kedua kaki lumpuh dan tidak bisa digerakan dengan kehilangan rasa mulai dari dada sampai ujung kaki.

Penelitian ini mendapatkan 6(enam) buah tema, yaitu 1) Kesedihan akibat kelemahan/perubahan fisik, 2) Merasakan adanya perubahan fungsi seksual, 3) Respon psikologis terhadap perubahan fungsi seksualitas, 4) Cara mengekspresikan fungsi seksual, 5) Harapan untuk memenuhi kebutuhan seksualnya, 6) Harapan terhadap pelayanan keperawatan di Rumah Sakit dalam mengatasi masalah kebutuhan seksual.

Kesedihan akibat adanya
kelemahan/perubahan fisik

Beberapa respon partisipan berupa kesedihan akibat kelemahan/perubahan fisik yang diungkapkan saat pertama kali didiagnosa dokter mengenai cedera medula spinalis bervariasi, ada yang menyatakan sedih nggak bisa jalan lagi dan hanya berada di kursi roda seperti pernyataan yang disampaikan oleh (P1) dan (P2) berikut ini :

"Ya sedih aja awalnya sehat wal afiat bisa jalan, punya pekerjaan namun setelah kecelakaan sama sekali tidak bisa jalan, tidak ada yang bisa dilakukan hanya menunggu bantuan orang lain, nggak bisa jalan lagi hanya di kursi roda seperti ini ....”. (P1)

\section{Perubahan fungsi seksual}

Ekspresi seksual adalah bagian dari kebutuhan dasar individu. Pada bulan pertama setelah mengalami cedera medula spinalis sangat penting mendiskusikan kehilangan kemampuan ereksi, ejakulasi, dan kesuburan secara normal dapat merusak. Berikut ungkapan yang dialami mengenai perubahan fungsi seksualitas setelah mengalami cedera medula spinalis, sebagai berikut :

"akibat kecelakaan saya kehilangan rasa mulai dari pinggang sampai ke bawah terutama sekitar kemaluan akibatnya saya tidak bisa merasakan dan tidak bisa menjepit lagi (ya aa..)saat punya suami masuk ditambah sekarang kesulitan menahan kencing terutama saat akan hubungan intim”. (P1)

"Sebelum menikah pernah melakukan onani lamanya sekitar 2 menit tapi tidak berhasil mengeluarkan sperma, kalau sesudah menikah pernah sih istri membantu saya merangsang dengan memegang penis saya sampai ereksi dan membuat sakit tapi akhirnya nggak keluar juga spermanya kadang membuat saya kesal .” (P6)

Pengalaman penurunan libido akibat nyeri yang dirasakan berkepanjangan membuat salah seorang 
partisipan kehilangan pasangan seksualnya akibat tidak pernah memperhatikan kondisi pasangannya seperti yang diungkapkan berikut ini :

"Sebenarnya sejak mengonsumsi obat nyeri dosis tinggi membuat saya selalu mengantuk dan tidak ada gairah sama sekali terhadap istri sampai saya hiraukan keberadaan istri saya".(P5)

Respon psikologis terhadap perubahan fungsi seksual

Penurunan fungsi seksual klien dengan cedera medula spinalis dapat mempengaruhi kesehatan dan psikososialnya. Ini dapat ditemukan pada klien dengan kecenderungan depresi, cemas, dan gembira berlebihan.

Berdasarkan tujuan penelitian ini dimana peneliti ingin mengetahui pengalaman psikologis terhadap perubahan fungsi seksual dan makna dari berduka klien akibat cedera medula spinalis, namun setelah wawancara dan proses analisis dilakukan, peneliti hanya memperoleh sedikit informasi dari cerita mengenai pengalaman berduka. Ungkapan sedih yang mendalam lebih kepada kondisi tubuh secara menyeluruh. Respon psikologis yang dimaksud berupa ekspresi emosi klien saat mengetahui masalah yang muncul setelah cedera. Berikut beberapa pernyataan mengenai respon emosional partisipan terkait perubahan fungsi seksual :

"saya khawatir dengan perasaan suami sekarang saya ....merasa tidak mampu menjepit lagi sehingga suami merasa tidak pernah mendapat balasan"(P1)

Pengertian dan penerimaan kondisi pasangan sejak sebelum menikah menjadikan komitmen keberlangsungan hubungan selama ini, seperti yang diungkapkan berikut :

"saya merasa minder melihat lawan jenis dengan kondisi saya di kursi roda apalagi kemaluan saya hanya bisa bangun tanpa bisa mengeluarkan sperma apalagi mimpi basah”. (P6)

\section{Cara mengekspresikan fungsi seksualnya}

Cara mengekspresikan fungsi seksual pada masing-masing pasangan bervariasi Berikut beberapa ungkapan yang disampaikan partisipan :

Perasaan tidak nyaman dialami partisipan yang mengalami cedera medula spinalis namun ditinggalkan suaminya begitu saja tanpa perceraian dan baru beberapa tahun kemudian setelah tinggal di satu panti mulai memberanikan diri untuk menikah dengan orang normal dalam artian tidak pernah mengalami cedera medula spinalis sehingga mendapatkan pengalaman yang unik karena pasangan nampaknya belum bisa beradaptasi seperti yang disampaikan berikut:

"Dengan kondisi saya yang belum bisa mengatur kencing setelah kecelakaan ......saat suami minta suka bilang sih tunggu ya 'aa' aku mau kencing dulu kebelet banget nih, 'aa' nih aku udah selesai kencingnya ayo kita naik, kadang si aa menolak dan udah lama dirayu baru dia mau diajak”. (P1)

Ada dua pasangan yang sudah membina hubungan saling percaya dan memahami kondisi fisik masing-masing mungkin membuat mereka bisa beradaptasi seperti pernyataan mereka sebagai berikut :

"Menyempatkan waktu untuk sayangsayangan di rumah”. (P4)

\section{Harapan untuk memenuhi kebutuhan seksualnya}

Beragam alasan diungkapkan para partisipan mengenai harapan dalam memenuhi kebutuhan seksualnya, seperti (P1) demi menjaga kelangsungan rumah tangga dan bisa memenuhi perannya sebagai istri bagi suami dan ibu bagi anaknya selalu menjaga keharmonisan pasangan sambil mencari dukungan dari teman-teman sesama paraplegi saat ke 
rumah sakit ataupun bermain ke panti dimana dia berasal seperti pernyataannya sebagai berikut :

"Selama ini hanya pasrah .......(sambil tertawa) dan berharap istri bisa kembali sih namun saat ini untuk mencari perempuan lain belum terpikir"(P5)

"Ingin menikah lagi dan mempunyai keturunan” (P3)

\section{Harapan terhadap pelayanan keperawatan di rumah sakit dalam mengatasi masalah kebutuhan seksual}

Sejak awal kecelakaan setiap klien yang mengalami cedera medula spinalis belum memahami bagaimana nasib selanjutnya ke depan. Beberapa harapan partisipan terhadap masalah seksual setelah cedera medula spinalis diungkapkan sebagai berikut:

"Bisa memberikan pencerahan atau informasi yang tepat dari tenaga kesehatan rumah sakit pada pasangan bagaimana cara mengatasi masalah yang dialami setelah cedera medula spinalis".(P6)

\section{Pembahasan}

\section{Kesedihan akibat adanya kelemahan/perubahan fisik}

Kelemahan/kelumpuhan

ekstremitas bawah awalnya membuat partisipan merasa sedih akibat lumpuh atau tidak mampu berjalan, sangat ketergantungan pada orang lain, mereka merasa tidak ada yang bisa dikerjakan dengan keterbatasannya, kehilangan pekerjaan, kehilangan pasangan hidup setelah mengalami cedera medula spinalis, bahkan ada satu partisipan yang merasa kehilangan semangat hidup karena sewaktu sehat berperan sebagai tulang punggung pengganti orang tua.

Pernyataan emosional adanya kelemahan/perubahan fisik setelah cedera medula spinalis tersebut menyebabkan kesedihan yang mendalam dari para partisipan sama dengan yang dikemukakan Dezarnaulds (2014) dalam penelitiannya bahwa terjadi reaksi emosi berupa kesedihan dan menangis, ketakutan tidak ada yang mampu dikerjakan dan kehilangan kontrol setelah cedera medula spinalis. Bagaimanapun, tidak hanya orang yang mengalami cedera medula spinalis yang merasa terbebani akibat cedera tersebut tapi juga semua keluarga besar terlibat (Chan, 2000).

\section{Perubahan fungsi seksual}

Perubahan fungsi seksual pada lakilaki seperti ketidakmampuan untuk ejakulasi merupakan hal yang sering dialami klien dengan cedera medula spinalis seperti yang dialami partisiapan (P3), (P5), dan (P6). Hal ini sesuai dengan penelitian yang dilakukan oleh Falavigna, Asdrubal (2012) disebutkan bahwa laki-laki dengan CMS mengalami perubahan fungsi seksual dan ketidakmampuan ejakulasi untuk mendapatkan keturunannya. Cedera Medula Spinalis (CMS) bisa menjadikan suatu pengalaman yang dramatis seperti cedera yang disertai kehilangan fungsi sensorik dan motorik, serta kerusakan fungsi seksual yang dialami oleh seseorang dalam kehidupannya (Hess \& Hough, 2012).

Laki-laki dengan cedera low incomplete hanya mengalami psychogenic erection. Banyak laki-laki dengan CMS dapat mengalami reflex erection dengan rangsangan fisik jika syaraf S2-S4 tidak mengalami kerusakan (Hess \& Hough, 2012). Banyak laki-laki dengan CMS mampu mempertahankan ereksi hanya ketika penis dirangsang saat melakukan aktivitas seksual (K. Connell, 2014). Penurunan (sexual arousal) dan hasrat bercinta (sexual desire) merupakan faktor yang sering terjadi setelah cedera medula spinalis dimana kesulitan dalam sexual arousal berhubungan dengan menurunnya kepuasan seksual (K. Connell, 2014).

Bagi partisipan wanita seperti yang disampaikan oleh (P1) dan (P2) dimana 
fungsi seksualnya masih lebih baik serta masih mengalami menstruasi. Hal ini sama dengan hasil penelitian yang dilakukan Khanal, (2013) dinyatakan bahwa wanita dengan CMS dapat hamil tergantung dari level/tingkatan dari cedera, mungkin juga akan mendapatkan kesulitan transferring, masalah dengan perkemihan, infeksi saluran kemih, autonomic dysreflexia dengan cedera diatas T6, konstipasi, kelahiran prematur dan kehilangan kontraksi uterus dengan lesi diatas T10. Menstruasi pada seorang wanita yang mengalami cedera medula spinalis sangat penting (M.Alexander, 2007)

Seksualitas merupakan suatu hal yang dinamis yangmana sangat mempengaruhi perkembangan seseorang seperti faktor biologis, psikologis, sosiologis, spiritual dan budaya dalam hubungan interpersonal (K.Connell, 2014). Efek pada respon seksual tergantung pada level dan beratnya cedera seperti status hubungan, pengalaman seksual (Hess \& Hough, 2012). Aktivitas seksual merupakan salah satu aktivitas yang penting dalam kehidupan sehari-hari setiap individu terutama yang sudah menikah dan aktivitas seksual ini juga merupakan konsentrasi utama seorang laki-laki dengan masalah cedera medula spinalis (Phelps, Albo, Dunn, \& Joseph, 2001).

Pada fase rehabilitasi dimana seseorang dengan cedera medula spinalis baik yang sudah menikah dan baru mengalami cedera ataupun pasangan yang baru saja menikah dan mengalami cedera sudah mulai mengetahui perubahan fungsi seksual yang terjadi yang seharusnya masing-masing pasangan sudah mulai dilibatkan pada situasi baru untuk belajar beradaptasi yang lebih baik (S. Angel. 2011). Seperti yang dinyatakan oleh Falavigna, Asdrubal (2012), bahwa laki-laki dengan CMS mengalami perubahan fungsi seksual dan ketidakmampuan ejakulasi untuk mendapatkan keturunannya, namun perubahan fungsi seksual akan tergantung pada level dan beratnya cedera (Hess \& Hough, 2012). Pendidikan seksual masih kurang untuk diintegrasikan ke dalam proses rehabilitasi (Hess \& Hough, 2012).

\section{Respon psikologis terhadap perubahan fungsi seksual}

Respon psikologis yang dirasakan partisipan terhadap perubahan fungsi seksual akibat cedera medula spinalis adalah timbulnya rasa minder, khawatir terhadap pasangan yang diungkapkan saat wawancara mendalam pada proses pengambilan data. Kehilangan sesuatu yang berharga bagi seseorang sangat bermakna yang mungkin bisa menimbulkan respon emosional. Pengalaman emosional sangat berakibat terhadap kehidupan seksualitasnya secara keseluruhan (Akman, Çel k, \& Karataş, 2015).

Setiap perubahan yang terjadi pada seseorang, baik berupa fisik, spiritual, emosi, seksual, keluarga dan sosial budaya merupakan stressor (Potter dan Perry, 2005). Stressor yang dialami partisipan berupa dampak dari cedera medula spinalis seperti kehilangan pekerjaan, perubahan peran, ataupun hubungan pasangan seksual. Seksualitas merupakan salah satu komponen utama dari kehidupan. Stress merupakan respon psikologis yang mempengaruhi kognitif, emosional, dan behavior (Potter \& Perry, 2007). Seksualitas juga merupakan sesuatu yang dinamis yang mana saling mempengaruhi biologi, psikologi, sosiologi, spiritual, dan faktor budaya yang mempengaruhi perkembangan seseorang dan kemampuan dalam hubungan dengan orang lain ( $\mathrm{K}$, Connel, 2014).

Seorang perawat perlu mengenal dan memahami mengenai masalah stress yang terjadi pada klien selama perawatan begitupun anggota keluarga yang mendampingi sehingga intervensi keperawatan yang diberikan akan lebih efektif (Potter \& Perry, 2007). 


\section{Cara mengekspresikan fungsi seksualnya}

Setelah CMS banyak sekali yang terjadi diluar kebiasaan misalnya perubahan ekspresi yang timbul dengan sendirinya seperti yang diperlihatkan (P2), (P4), (P6) saat menceritakan bagaimana ekspresi seksual dan keintiman pasangan seksualnya seperti beberapa partisipan yang lebih berani untuk berfantasi dan lebih mempersiapkan diri untuk aktivitas seksualnya seperti pelukan, ciuman, rangsangan manual dan rangsangan genital untuk lebih meningkatkan rasa nyaman pasangan yang mungkin sangat berbeda dengan pasangan yang tidak mengalami CMS.

Pernyataan yang didapatkan peneliti dari beberapa partisipan selama wawancara mendalam berupa cara mengekspresikan fungsi seksual sangat bervariasi mulai dari kewajiban melayani pasangan sampai kesetiaan terhadap pasangan seksualnya seperti yang dilakukan oleh beberapa partisipan P1, P2, P4, dan P6. Seksualitas menyangkut banyak aspek kehidupan yang diekspresikan dalam bentuk perilaku yang beraneka ragam seperti yang dikemukakan oleh Hess \& Hough (2012) bahwa faktor hubungan seperti kepuasan pasangan dan kualitas hubungan merupakan hal yang sangat penting dari kepuasan seksual daripada fungsi genital bagi laki-laki maupun wanita dengan CMS.

Seksualitas merupakan komponen utama dari kualitas hidup individu dan membahas mengenai seksual masih dianggap hal yang tabu (taboos) pada banyak budaya sehingga dapat menyebabkan rasa ketidaknyamanan baik bagi individu, orang tua, dan profesional (R. Crawshaw, 2006). Mendiskusikan masalah seks seperti sebuah topik istimewa yang awalnya sering dirasakan tidak nyaman dan selalu dihindari untuk dibicarakan sehingga menjadikan partisipan kurang terbuka baik pada pasangan seksnya maupun peneliti yang ingin mendapatkan gambaran perubahan fungsi seksual setelah cedera medula spinalis karena masih dianggap suatu masalah yang sensitif dan bersifat pribadi sehingga pada awal pertemuan menjadikan satu kendala yang sangat berarti. Sangat tidak mudah untuk mendapatkan informasi mengenai respon seksual dari partisipan dimana pada awal pertemuan belum terbinanya hubungan saling percaya diantara kedua belah pihak apalagi sebagai peneliti pemula.

\section{Harapan untuk memenuhi kebutuhan seksualnya}

Pengalaman yang diungkapkan partisipan tentang harapan pemenuhan kebutuhan seksualnya dibutuhkan pemahaman serta penerimaan dari pasangan seksualnya mengenai kondisi seksual setelah cedera medula spinalis. Harapan yang diinginkan partisipan setelah mengalami cedera medula spinalis adalah kembali pada kondisi normal, namun penting sekali klien dengan cedera medula spinalis memahami apa arti dari harapan tersebut.

Hal ini sesuai dengan pernyataan Dufault \& Martocchio (1985) di dalam hasil penelitiannya yang menggambarkan bahwa harapan sebagai kekuatan yang multidimensi dan dinamis dalam kehidupan seperti harapan positif, kemungkinan yang realistis. Penerimaan kondisi seksual setelah CMS sangatlah penting terutama pasangan seksualnya karena mungkin laki-laki mengalami kehilangan kepuasan seksualnya, percaya diri, dan nilai sedangkan wanita terjadi penurunan hasrat bercinta sehingga mereka mendapatkan kenikmatan lebih kepada dengan pegangan tangan, pelukan,dan ciuman saat hubungan seksual(Torriani, Simone Beatriz Britto, Flavia Costa, 2014). Tidak terpenuhinya kebutuhan seks dapat menimbulkan rasa bersalah dan penolakan sehingga menyebabkan permasalahan dalam pola 
hubungan pasangan (Benevento, Barbara T dan Sipski, 2002).

Seksualitas adalah tentang bagaimana seseorang mengalami, menghayati, dan mengekspresikan diri sebagai mahluk seksual, bagaimana seseorang berfikir, merasa dan bertindak berdasarkan posisinya sebagai mahluk seksual, yaitu bagaimana mereka mengkomunikasikan perasaan tersebut kepada orang lain melalui tindakan yang dilakukannya seperti sentuhan, pelukan, ataupun berupa isyarat, gerak tubuh,dan cara berpakaian. (WHO, 2013). Kekuatan yang muncul dari seseorang atau pasangan untuk menerima dan setuju dengan kondisi kehidupan pasangan seksualnya dengan perubahan yang terjadi. Dampak dari cedera medula spinalis pada respon seksual tergantung derajat dan lokasi dari cedera(M. Benevento, 2002).

\section{Harapan terhadap pelayanan keperawatan di rumah sakit dalam mengatasi masalah kebutuhan seksual}

Partisipan yang mengalami cedera medula spinalis terutama perubahan fungsi seksual pada penelitian ini berharap pada praktisi kesehatan di rumah sakit dimana partisipan pernah dirawat dan mendapatkan edukasi serta berbagai pengalaman terutama di ruang rawat rehabilitasi pasca cedera medula spinalis, pengaruh dan dukungan dari keluarga, sesama paraplegi, dan tenaga kesehatan hingga terbina hubungan saling percaya, sikap perawat yang lebih perhatian, adil, lebih ramah, lebih sabar, terampil serta bertanggungjawab bahkan beberapa partisipan mengharapkan adanya konseling gratis yang diselenggarakan pihak rumah sakit terutama masalah kehidupan dan masalah seksual yang mereka alami terutama setelah menikah.

Proses rehabilitasi orang dengan cedera medula spinalis bertujuan agar individu mampu beradaptasi pada kondisi terbaru sekarang. Rehabilitasi setelah cedera medula spinalis harus mendapat dukungan secara otomatis dan terintegrasi ke dalam keluarga, masyarakat, dan lingkungan kerja sebagai proses penerimaan dari kesulitan dan keterbatasan seseorang diluar seksualitas dan kesehatan seksual (S.Torriani, F. Britto, G. Aguiar, 2014).

Berbagai tantangan yang harus dihadapi baik secara fisik maupun psikologis seseorang dengan cedera medula spinalis sangatlah bervariasi tergantung pada level dari cedera dan derajat kerusakan syaraf yang dialami (M. Benevento, 2002). Bagaimanapun, tidak hanya orang dengan cedera medula spinalis yang merasakan efek dari cedera tapi juga seluruh anggota keluarga ikut merasakan (Chan, 2000).

Perawat dituntut mampu mengatasi masalah kebutuhan adaptasi selama masa perawatan. Perawat membantu memfasilitasi dengan menciptakan peer group discussion yang mempunyai pengalaman yang sama untuk mendapatkan support system selain dari keluarga. Sebagaimana proses adaptasi yang dikemukakan oleh Callista Roy, dimana manusia sebagai makhluk biopsikososiospiritual yang tetap berinteraksi dengan perubahan lingkungan sebagai respon adaptasi sehat dan sakit.

\section{Kesimpulan}

Penelitian ini memberi gambaran perubahan yang sangat berarti terhadap seksualitas akibat Cedera Medula Spinalis (CMS). Hasil-hasil yang ditemukan menjadi pelengkap terhadap hasil penelitian lainnya terkait seksualitas pada CMS. Diharapkan tema ini dapat dijadikan bahan penelitian lanjutan.

\section{Ucapan Terima Kasih}

Ucapan terima kasih disampaikan kepada pimpinan dan staf rumah sakit dimana penelitian ini dilaksanakan, para partisipan, serta teman-teman komunitas paraplegi yang telah berpartisipasi dan mendukung dalam penelitian ini. 


\section{Daftar Pustaka}

Afiyanti, Y., \& Rachmawati, I. N. (2014). Metodologi Penelitian Kualitatif dalam Riset Keperawatan (1st ed.). Jakarta: Rajawali Pers.

Akman, R. Y., Çel k, E. C., \& Karataş, M. (2015). Sexuality and sexual dysfunction in spinal cord-injured men in Turkey. Turkish Journal of Medical Sciences, $\quad 5, \quad 45-48$. http://doi.org/10.3906/sag-Sexuality

Alexander, M. S. (2007). Recommendations for discussing Sexuality After Spinal Cord Injury. Journal Spinal Cord Medicine, 30.

Ali, S. A., \& Rahopoto, M. Q. (2014). Impact of Trauma on Marital Life 4, 11(4), 473-477. http://doi.org/10.5829/idosi.wjms.2014. 11.4 .8682

Angel, S., \& Buus, N. (2011). The experience of being a partner to a spinal cord injured person: A phenomenological-hermeneutic study. International Journal of Qualitative Studies on Health and Well-Being, 6(4), $1-11$. http://doi.org/10.3402/qhw.v6i4.7199

Becker, D., Sadowsky, C. L., \& Mcdonald, J. W. (2003). RESTORING FUNCTION AFTER. The Neurologist, 9.

Benevento, Barbara $\mathrm{T}$ dan Sipski, M. L. (2002). Spinal Cord Injury Special Series Neurogenic Bladder, Neurogenic Bowel, and Sexual Dysfunction in People With Spinal Cord Injury. Neurogenic Bladder, Neurogenic Bowel, 601-612.

Biko, S., Hospital, A., Biko, S., \& Hospital, A. (2010). Efficacy of sexual counselling during the rehabilitation of spinal cord injured patients, 45-48.

Cense, M. (2014). Culture, Health \& Sexuality: An International Journal for Research , Intervention and Care Sexual discourses and strategies among minority ethnic youth in the Netherlands, (June), 37-41. http://doi.org/10.1080/13691058.2014. 918655

Centre, T. N. S. C. I. S. (2014). Spinal cord injury facts and figures at a glance. The Journal of Spinal Cord Medicine, $37(4)$,

479-80.
http://doi.org/10.1179/1079026814Z.00 0000000322

Chandra, A., Ph, D., Mosher, W. D., Ph, D., Copen, C., Ph, D., \& Statistics, V. (2011). Sexual Behavior , Sexual Attraction, and Sexual Identity in the United States: Data From the 2006 2008, 19(36).

Conaglen, J. (2004). The assessment and management of common male sexual difficulties in family practice Continuing Medical Education Con, 31(1), 20-27.

Connell, K. M., Coates, R., \& Wood, F. M. (2014). Sexuality following trauma injury: A literature review, 2(2). http://doi.org/10.4103/23213868.130189

Crawshaw, R. B. and M. (2006). sexuality and fertility issues in ill health and disability. (M. Balen, Rachel and Crawshaw, Ed.). London: Jessica Kingsley.

Creswell, J. W. (2003). Research design Qualitative,quantitative, and mix method approaches. (C. D. Laughton, Ed.) (Vol. secod edit). Calofornia.

Creswell, J. W. (2007). QUALITATIVE Choosing Among Five Approaches. (L. C. Shaw, Ed.) (Second Edi). California: Sage Publication.

Cripps, R. A. (2007). Spinal cord injury, Spinal cord injury, Australia ,.

Dezarnaulds, A. (2014). Psychological Adjustment after Spinal Cord Injury.

Dibb, B., Ellis-hill, C., Donovan-hall, M., \& Burridge, J. (2014). Exploring positive adjustment in people with spinal cord injury, 19(8), 1043-1054. http://doi.org/10.1177/1359105313483 158

Dumont, R. J., Okonkwo, D. O., Verma, S., Hurlbert, R. J., Boulos, P. T., Ellegala, D. B., \& Dumont, A. S. (2001). Acute Spinal Cord Injury, Part I: Pathophysiologic Mechanisms. Clinical Neuropharmacology, 24(5), 254-264.

Ellenbogen, P. S., Meade, M. A., Jackson, M. N., \& Barrett, K. (2006). The impact of Spinal Cord Injury on the employment of family caregivers, 25, $35-44$

Everaert, K., Waard, W. I. Q. De, Hoof, T. Van, Kiekens, C., Mulliez, T., \& D, C. (2010). Neuroanatomy and 
neurophysiology related to sexual dysfunction in male neurogenic patients with lesions to the spinal cord or peripheral nerves, (November 2009), 182-191.

http://doi.org/10.1038/sc.2009.172

Fahs, B., Frank, E., Fahs, B., \& Frank, E. (2014). Notes from the Back Room: Gender, Power, and ( In ) Visibility in Women , s Experiences of Masturbation Notes from the Back Room: Gender, Power, and ( In ) Visibility in Women' $s$ Experiences of Masturbation, (March), 37-41. http://doi.org/10.1080/00224499.2012. 745474

Falavigna, Asdrubal, et al. (2012). Spinal Cord injury and male infertility: a review, 11(4), 322-325.

Garrett, A., José, R., Evangelista, G., \& Alcochete, F. (2012). Impact of Spinal Cord Injury in Affective Relationship: A Qualitative Analysis of the Subjects, Perception, 2(1), 1-6.

Hess, M. J., \& Hough, S. (2012). Impact of spinal cord injury on sexuality: Broadbased clinical practice intervention and practical application. Journal of Spinal Cord Medicine, 35(4), 211-218. http://doi.org/10.1179/2045772312Y.00 00000025

Holstege, G., Georgiadis, J. R., Paans, A. M. J., Meiners, L. C., Graaf, F. H. C. E. Van Der, \& Reinders, A. A. T. S. (2003). Brain Activation during Human Male Ejaculation, 23(27), 9185-9193.

Hu, X., Zhang, X., Gosney, J. E., Reinhardt, J. D., Chen, S., Jin, H., \& Li, J. (2012). Analysis of functional status, quality of life and community integration in earthquake survivors with spinal cord injury at hospital discharge and oneyear follow-up in the community. Journal of Rehabilitation Medicine, 44(3), 200-205. http://doi.org/10.2340/16501977-0944

Kawanishi, C. Y., \& Greguol, M. (2013). Physical Activity, Quality Of Life , and Functional Autonomy of Adults With Spinal Cord Injuries, 317-337.

Khanal, D. (2013). Education on Sexual Life in Spinal Cord Injury Patients: A Missing Link in Physiotherapy. Journal of Novel Physiotherapies, 03(01), 1-2. http://doi.org/10.4172/2165-

7025.1000124

Lit, A. Van. (2014). A narrative review of hope after spinal cord injury: Implications for physiotherapy. New Zealand Journal, 33-42.

Lombardi, G., Popolo, G. Del, Macchiarella, A., Mencarini, M., \& Celso, M. (2010). Sexual rehabilitation in women with spinal cord injury: a critical review of the literature. Spinal Cord, 48(12), 842-849.

http://doi.org/10.1038/sc.2010.36

Middleton, J., Perry, K. N., \& Craig, A. (2014). Physical Medicine \& Rehabilitation A Clinical Perspective on the Need for Psychosocial Care Guidelines in Spinal Cord Injury Rehabilitation. International Journal Physical Medical Rehabilitation. http://doi.org/10.4172/23299096.1000226

Mona, L. R., Cameron, R. P., Goldwaser, G., Miller, A. R., Syme, M. L., \& Fraley, S. S. (2009). Prescription for Pleasure: Exploring Sex-Positive Approaches in Women with Spinal Cord Injury, 15(1), 15-28. http://doi.org/10.1310/sci150115

Occ, J. R. B., Ukzn, T., Occ, A. F. B., \& Ukzn, T. (2011). A pilot study on sexuality in rehabilitation of the spinal cord injured: exploring the woman' $\mathrm{s}$ perspective, 4l(2).

Perrys, \& S, P. dan. (2004). Fundamentals of Nursing (4nd ed). Elsevier Ltd.

Pfaus, J. G. (2009). Pathways of sexual desire. Journal of Sexual Medicine, 6(6), 1506-1533. http://doi.org/10.1111/j.17436109.2009.01309.x

Polit, D. F., \& Beck, C. T. (2012). Nursing Research. (H. Surrena, Ed.) (ninth). Wolters Kluwer Health.

Polri, K. M. Indonesia Road Safety Award (2013).

Reitz, A., Tobe, V., Knapp, P. A., \& Schurch, B. (2004). Impact of spinal cord injury on sexual health and quality of life, (December 2003), 167-174. http://doi.org/10.1038/sj.ijir.3901193

Ricciardi, L., \& Edwards, M. J. (2014). Treatment of Functional ( Psychogenic ) Movement Disorders, 201-207. 
http://doi.org/10.1007/s13311-0130246-x

Rieger, G., Savin-Williams, R. C., Chivers, M. L., \& Bailey, J. M. (2015). Sexual Arousal and Masculinity-Femininity of Women. Journal of Personality and Social Psychology, (April 2016). http://doi.org/10.1037/pspp0000077

Sakellariou, D., \& Sawada, Y. (2006). Sexuality After Spinal Cord Injury: The Greek Male' s Perspective. The American Journal of Occupational Therapy, 60(3), 311-319. http://doi.org/10.5014/ajot.60.3.311

Sátiro, I., França, X. De, Coura, A. S., França, E. G. De, Basílio, N. V., \& Souto, R. Q. (2011). Quality of life of adults with spinal cord injury: a study using the WHOQOL-bref, 45(6), 13611368.

Settles, I. H., Buchanan, N. T., Yap, S. C. Y., \& Harrell, Z. a T. (2014). Sex differences in outcomes and harasser characteristics associated with frightening sexual harassment appraisals. Journal of Occupational Health Psychology, 19(2), 133-142. http://doi.org/http://dx.doi.org/10.1037/ a0035449

Shafrina, A., Julia, O., \& Engkasan, P. (2011). Sexual Dysfunction Following Spinal Cord Injury: the Experiences of Malaysian Women. http://doi.org/10.1007/s11195-0119207-7

Sharma, S. C., Singh, R., Dogra, R., \& Gupta, S. S. (2006). Assessment of sexual functions after spinal cord injury in Indian patients. International Journal of Rehabilitation Research. Internationale Zeitschrift Für Rehabilitationsforschung. Revue Internationale de Recherches de Réadaptation, 29(1), 17-25. http://doi.org/10.1097/01.mrr.00001855 947.56810.fc

Shepherd Center, KPKinteractive, Society, A. T., Association, N. S. C. I., \& Foundation, C. \& D. R. (2011). Understanding Spinal Cord Injury.

Smeltzer, S. C., Hinkle, J. L., Bare, B. G., \& Cheever, K. H. (2010). Brunner \& Suddarth's texbook of medical-surgical nursing. (Hilarie Surrena, Ed.) (12th ed.). Philadelphia: Wolter Kluwer Health Lippincott.

Streubert, H. J., \& Carpenter, D. R. (2003). Qualitative research in Nursing: Advancing the humanistic imperative. (3rd ed.). Philadelphia : Lippincott Williams \& Wilkins.

Torriani, S. B., Britto, F. C., \& Aguiar, G. (2014). Sexuality of People with Spinal Cord Injury: Knowledge, Difficulties and Adaptation, (May), 380-386.

Veith, E. M., Sherman, J. E., Pellino, T. a., \& Yasui, N. Y. (2006). Qualitative analysis of the peer-mentoring relationship among individuals with spinal cord injury. Rehabilitation Psychology, 51(4), 289-298. http://doi.org/10.1037/00905550.51.4.289

Wallace, M. A. (2008). Assessment of Sexual Health in Older Adults. American Journal of Nursing, 108(7).

Whalley Hammell, K. (2007). Experience of rehabilitation following spinal cord injury: a meta-synthesis of qualitative findings. Spinal Cord: The Official Journal of the International Medical Society of Paraplegia, 45(4), 260-274. http://doi.org/10.1038/sj.sc.3102034

WHO. (2013). International Perspective on Spinal Cord Injury. 